\title{
Landfill Site Selection Using GIS and (AHP): Case Study of Ranya City
}

\author{
Sarkar Hamad Khdir ${ }^{1}$, Kameran Taheer Saeed ${ }^{2}$ \\ ${ }^{1,2}$ Department of Geography, Faculty of Education, Koya University, Erbil, Kurdistan-IRAQ
}

\begin{abstract}
Ranya City is located in North West of Sulaymaniyah Governorate, Iraq. It has an area of (76.7) km2. In 2018, it was home for $(102,571)$ inhabitants. Presently, there are no landfills in the study area that fulfills necessary environmental requirements; thus, informal and unsuitable solid waste dumping is negatively impacting human health and the environment. Land fill site selection can be a difficult task as it is impacted by different factors and regulations. This study is an attempt to identify and evaluate suitable landfill locations in the study area using Analytical Hierarchy Process (AHP) and Geographic Information System (GIS). Ten criteria are used in this process which includes: groundwater depth, surface water, residential areas, Geological formations, slope, elevation, soil type, land use, roads and archeological sites. AHP was used to determine the weight for each criteria using pairwise comparison matrix. Three classes of suitability index were found: unsuitable (98.47\%), moderately suitable $(0.003 \%)$ and suitable $(1.52 \%)$ of the study area. Three suitable landfill sites were identified as candidate sites that meet the requirements with an area of $(0.29) \mathrm{km} 2,(0.12) \mathrm{km} 2$ and $(0.098) \mathrm{km} 2$ respectively.
\end{abstract}

KEYWORDS: Ranya City; Landfill; GIS; AHP; Solid Waste.

\section{Introduction}

Municipal Solid Waste (MSW) disposal is one of the most critical environmental issues in the world [1]. Globally, more than 3 million tones of solid waste are produced daily [2]. Improving living standards, Urbanization, population growth, industrial and commercial activities are main reasons for a drastic increase in solid waste generation in urban areas [3]. Solid waste issue is particularly problematic in third world countries which are heavily populated and struggling financially. Due to the circumstances of these countries, such waste is negatively influencing both human health and the environment [4].

There are a variety of methods used to manage solid waste such as source reduction, reuse, recycling, incineration, landfills, and waste transformation [5]. However, even after the recovery method, there is always some residual for disposal. Sanitary landfills have been used in many countries as the main method for waste management as it is considered to be simple and cheap compare to other ways of waste management [6].
Landfill siting is a relatively difficult assignment for authorities as it depends on many regulations factors. Additionally, decreased amount of governmental and municipal funding, land availability, increasing environmental understanding, and public health concerns, political and social opposition are also pressing factors when it comes to landfill siting [7]. City of Ranya has undergone rapid urbanization since 2003, and solid waste generation quantity has also grown at a high rate. This has caused negative impacts on the environment and public health. In 2018, Ranya city generated $(31,822)$ tonnes of solid waste annually. At the moment, there is no landfill site in Ranya that fulfills environmental and scientific requirements. There are a few disposal sites scattered around the parameters of the city where people dispose solid waste without supervision and approval from authorities. Despite of unsupervised solid waste disposal, further environmental damage comes from poor solid waste management by the municipality of the city where they collect solid waste in the city and 
they dispose it in a large open dumpsite at southern parts of the city without any pre-treatment. Therefore, selecting a suitable site that meets social, environmental and economic criteria is significant for future development of Ranya city.

This study used the concepts of GIS and AHP which are great methods when combined together to select suitable landfill locations. AHP is developed by Saaty (1980) as a multi-criteria decision making (MCDM) method to unite multi criteria in the decision making [8]. Researchers in many fields used (MCDM) and GIS as a tool to answer difficult decision problems such as the possibility of groundwater pollution [9], soil environments [10], land evaluation for urban agriculture [11], urban planning and hospital site selection [12]. Also, GIS and AHP as a combined tool have been widely utilized by many researchers to identify and select landfill sites that are most suitable $[13,14,15,8,16,17,18,19,20,21,22]$.

The objective of this research is to select suitable landfill sites in Ranya City that meets environmental and scientific requirements. In order to achieve this objective, ten criteria that influence solid waste management and the environment were selected through combining AHP and GIS. AHP was used to decide the weight of each influencing factor by creating a pairwise comparison matrix, and GIS as an integral part of landfill site selection is used to manage and display data efficiently from different sources in a reduced time and cost $[23,5]$.

\section{Study Area}

Ranya is one of the major cities in Sulaymaniyah Governorate, Iraq. It is located between latitude $36^{\circ} 11^{\prime} 07^{\prime \prime}-36^{\circ} 17^{\prime} 47^{\prime \prime}$ North and longitude $44^{\circ} 49^{\prime} 39^{\prime \prime}-44^{\circ} 59^{\prime} 23^{\prime \prime}$ East covering an area of about (76.7) $\mathrm{km}^{2}$ (Figure 1). It is (131) $\mathrm{km}$ northwest Sulaymaniyah. The city is situated on Bitwen plain and is surrounded by Kewarash mountain series from north, Hajila Mountain from west and Dukan Lake from south. Regarding climate of the study area; it is characterized by hot-dry summer and rainy cold winter. The annual rainfall average is about $705 \mathrm{~mm}$, and annual temperature average is about $\left(32.3^{\circ} \mathrm{C}\right)$. The population of Ranya city was $(102,571)$ inhabitants in 2018.

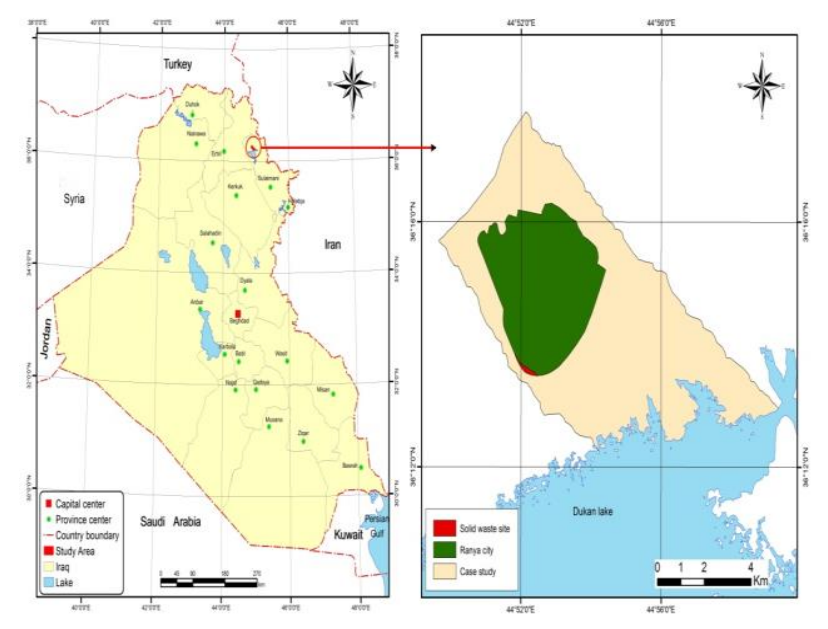

Figure 1: Study area location based on Iraq and Sulaymaniyah Governorate.

\section{Materials and Methods}

In order to select a suitable landfill site in the study area, we combined AHP and GIS and followed methodology described below [24, 25, 26]. Ten different layers of maps of the most significant criteria covering the study area were prepared using spatial analysis tools in Arc GIS 10.8, based on criteria selected in this study, the model of landfill site selection followed below steps:

- Preparing a digital data set of spatial features using Arc GIS 10.8.

- Creating buffer zones around critical areas using buffer tool.

- Using expert opinion, government regulations, and literature to decide the weightings of the subcriteria.

- Using AHP to determine the weightings of each criterion.

- $\quad$ Finding suitability index for candidate sites.

\subsection{The Hierarchial structure for Landfill Site}

\section{Selection}

The hierarchical structure was built based on the government regulations, previous research, opinions 
of experts in urban planning, and data availability in the study area. The hierarchy consists of three levels (Figure 2). The first level includes two general categories: natural environment factors and artificial factors. The second level represents five factors including hydrological criteria, land, topographical criteria, accessibility, and social-cultural criteria. The third level includes all ten criteria that are used in this study.

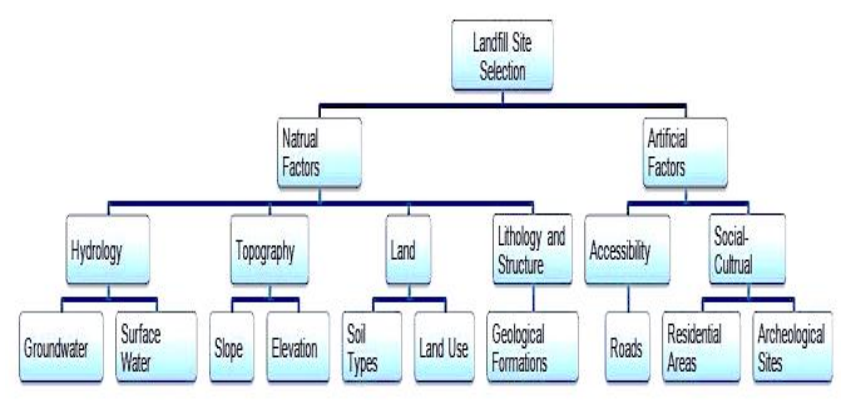

Figure 2: Landfill siting Hierarchical diagram

Groundwater depth in the study area ranges from (8 to 40) $\mathrm{m}$ below ground in most of the area; this depth is considered low. The landfill site must be situated in an area with deep groundwater table to minimize likelihood of groundwater pollution from solid waste leachate [27, 28].Surface water is one of the most significant factors in this study, because the study area has Dukan Lake at its southern border which is one of the major lakes in the region. This criterion is used in the study to keep surface water from and pollutants from solid waste leachate [29].

Distance from residential areas is critical when it comes to landfill site selection. Solid waste landfills should not be close to residential areas including urban centers and villages [1]. In this context, residential areas are marked as restricted in this study.

Elevation criterion was adopted in this study to address the risk of flooding and feasibility of landfill construction and waste transportation[30]. Slope is considered as a significant criterion to decide the most suitable site for landfill particularly from a construction and operations perspective, also steep slope would cause leachate drainage into lower lands [31].

Geological formation criterion describes the outcropped and subsurface lithology, landfill construction should not be close to unstable and active faults [24]. Road is an important criterion for landfill site selection. Distance from road to landfill should be sufficient to eliminate negative aesthetic impacts. Furthermore, landfills should be within a reasonable distance from road to facilitate waste transportation and reduce the cost [25].

Land use classification was used to adopt land use criterion and were ranked based on their suitability for landfill site [24, 3]. Regarding soil criterion, three different types of soil can be identified, but soil of the study predominantly consist of alluvial and slop deposits. This criterion was incorporated into the study protect soils of the study area from pollution. Archeological sites criterion was used to preserve archeological sites from destruction. Landfills should be from a sufficient distance from archeological sites to reduce negative impact on them.

\subsection{Buffer Zones Around Restricted Sites}

Buffer zones were formed around some particular geographic featuers using spatial analysis tool in Arc GIS 10.8. Buffer zones are created to minimize or reduce the impact of landfill site on human health, the wider enevironment and complying with government regulations [8]. Literature and expert opinion were used to create buffer zones at a distnace from each featuer for the selected criteria, however due to land availability in the study area, some buffer zones were modified Table 1.

Table 1: Suggested buffer zone values of the study

\begin{tabular}{cccc}
\multicolumn{3}{c}{ Area } \\
\hline No. & Criteria & Buffer Zone & $\begin{array}{c}\text { Researcher } \\
\text { Suggestions }\end{array}$ \\
\hline 1 & Surface Water & $1000 \mathrm{~m}$ & {$[32,33,34]$} \\
2 & Roads & $500 \mathrm{~m}$ & {$[25,24]$} \\
3 & Groundwater & $<8 \mathrm{~m}$ & {$[5,35,26]$} \\
4 & Elevation & $>820 \mathrm{~m}$ & {$[30,21]$} \\
5 & Residential Area & $1000 \mathrm{~m}$ & {$[36,37,38,25]$} \\
\hline
\end{tabular}




\begin{tabular}{cccc}
\hline 6 & Slope & $>15$ degrees & {$[26,5]$} \\
7 & Archeological Site & $1000 \mathrm{~m}$ & {$[39,8,24]$} \\
8 & Land Use & Exclude & {$[11,13,24]$} \\
& & Residential & \\
\hline \hline
\end{tabular}

\subsection{Source of Data}

In order to prepare the final map of landfill site selection, a map layer for each criterion was created using Arc GIS 10.8 spatial analysis tool. The source of data comes from government agencies, international organizations and field work. The first source is government available data including geological formation, soil types[40], residential area, roads, land use, and archeological sites[41]. The second source of data is from international organization such USGS including elevation, slope, and surface water. Groundwater depth data was collected during field work and "Kriging" method was used to create groundwater table for study area. Arc GIS 10.8 was used to convert digital data into format file.

\subsection{Sub-Criteria Classification and Rating}

Each criterion was divided into sub-criteria and was given a rating value from (zero to ten) based on their suitability (Table 2.). Sub-criteria classification was performed based on data availability, literature, government regulations, expert opinion and land availability in the study area. In order to prepare layer maps for each criterion and sub-criteria, a number of functions were used in Arc GIS 10.8 spatial analysis tools such as "Buffer, Clip, Extract, Overlay, Proximity, Convert, Reclassify, and Map Algebra".

The layer of surface water was classified into two buffer zones, (0-1) $\mathrm{km}$ which is given suitability value of (0) to eliminate the risk of water pollution, and greater than (1) $\mathrm{km}$ which is given a rating value of (10) (Figure 3. A). for the groundwater layer map, "Kriging" method was used to obtain interpolation between groundwater depth for groundwater samples taken from wells in the study area. The groundwater level measurement was obtained during a field visit in 2018. Landfill siting is significantly impacted by groundwater depth due to pollution through leachate leaking. In this paper, groundwater is classified into five classes of depth: (0-8) m, (8-16) m, (16-24) m, (2432 ), and greater than (32) $\mathrm{m}$ with rating values of 0,3 ,

Table 2: Sub-criteria Rating and Buffer Zone

\begin{tabular}{|c|c|c|c|}
\hline Number & Criterion & Buffer Zones & $\begin{array}{l}\text { Rating } \\
\text { Value }\end{array}$ \\
\hline \multirow{2}{*}{1} & Surface Water & $0-1$ & 0 \\
\hline & $(\mathrm{km})$ & $>1$ & 10 \\
\hline \multirow{5}{*}{2} & \multirow{5}{*}{$\begin{array}{l}\text { Groundwater } \\
(\mathrm{m})\end{array}$} & $0-8$ & 0 \\
\hline & & $8-16$ & 3 \\
\hline & & $16-24$ & 7 \\
\hline & & $24-32$ & 9 \\
\hline & & $>32$ & 10 \\
\hline \multirow{4}{*}{3} & \multirow{4}{*}{$\begin{array}{l}\text { Residential } \\
\text { Area }\end{array}$} & $0-1000$ & 0 \\
\hline & & $1000-1500$ & 3 \\
\hline & & $1500-2000$ & 7 \\
\hline & & $>2000$ & 10 \\
\hline \multirow{5}{*}{4} & \multirow{5}{*}{ Elevation (msl) } & $420-520$ & 8 \\
\hline & & $520-620$ & 10 \\
\hline & & $620-720$ & 9 \\
\hline & & $720-820$ & 4 \\
\hline & & $>820$ & 0 \\
\hline \multirow{4}{*}{5} & \multirow{4}{*}{ Slope (degree) } & $<5$ & 10 \\
\hline & & $5-10$ & 8 \\
\hline & & $10-15$ & 6 \\
\hline & & $>15$ & 0 \\
\hline \multirow{5}{*}{6} & \multirow{5}{*}{ Roads (m) } & $0-500$ & 0 \\
\hline & & $500-1000$ & 7 \\
\hline & & $1000-1500$ & 8 \\
\hline & & $1500-2000$ & 10 \\
\hline & & $>2000$ & 6 \\
\hline \multirow{5}{*}{7} & \multirow{5}{*}{ Land Use } & Residential & 0 \\
\hline & & Tourism & 2 \\
\hline & & Forestry & 5 \\
\hline & & Agriculture & 5 \\
\hline & & Unused Land & 10 \\
\hline \multirow{4}{*}{8} & \multirow{4}{*}{ Soil Types } & Chestnut Soils & 6 \\
\hline & & Shallow Phases & \\
\hline & & $\begin{array}{l}\text { Chestnut Soils } \\
\text { Deep Phases }\end{array}$ & 8 \\
\hline & & $\begin{array}{l}\text { Rough Broken } \\
\text { Stony Land }\end{array}$ & 10 \\
\hline \multirow{10}{*}{9} & \multirow{10}{*}{$\begin{array}{l}\text { Geological } \\
\text { Formations }\end{array}$} & $\begin{array}{l}\text { Aqra-Bekhma\& } \\
\text { Komitan }\end{array}$ & 2 \\
\hline & & Slope and & \\
\hline & & Alluvial fan & 6 \\
\hline & & Deposits & \\
\hline & & Balambo, & \\
\hline & & Sarmord\& & 4 \\
\hline & & Qamchuqa & \\
\hline & & ChiaGara, & \\
\hline & & $\begin{array}{c}\text { Barsrin\& } \\
\text { Naokelakan }\end{array}$ & 8 \\
\hline & & Sehkanian\& Sarki & 10 \\
\hline \multirow{5}{*}{10} & \multirow{5}{*}{$\begin{array}{l}\text { Archeological } \\
\quad \text { Site }(\mathrm{m})\end{array}$} & $0-1000$ & 0 \\
\hline & & $1000-2000$ & 3 \\
\hline & & $2000-3000$ & 5 \\
\hline & & $3000-4000$ & 7 \\
\hline & & $>4000$ & 10 \\
\hline
\end{tabular}

7, 9, and 10 respectively (Figure 3.B). Residential area layer map is divided into four classes, $(0-1000) \mathrm{m}$, 
(1000-1500) m, (1500-2000) m, and greater than (2000) $\mathrm{m}$ and receiving rating values of $0,3,7$, and 10 . In literature, most the researchers suggest a buffer zone of about $5 \mathrm{~km}$, but due to land availability in the study area, the restricted buffer zone is created within (1) km (Figure 4.A).

Elevation layer was obtained from Digital Elevation Model (DEM) for the study area and was classified into five categories including (420-520), (520-620), (620720), (720-820), and greater than (820) (MSL) and were given rating values of $8,10,9,4$, and 0 respectively. Appropriate elevation in this paper are given values of 8,9 , and 10, but any elevation above (820) $\mathrm{m}$ are considered restricted and are given value of (0) (Figure 4.B). Slope is divided into four classes: (0-5), (5-10), (1015), and greater than (15) degrees. Based on literature and expert opinion the best slope to consider for landfill site selection is (5); this is to avoid leachate transportation to lower areas (Figure 4.C).

The layer map of roads includes highways and main roads has been divided into five buffer zones of (0-500) $\mathrm{m},(500-1000) \mathrm{m},(1000-1500) \mathrm{m},(1500-2000) \mathrm{m}$, and greater than (2000) $\mathrm{m}$ and they were given rating values of $0,7,10,8$, and 6 respectively (Figure 4.D).

Land Use layer map was classified into five categories based on Ranya municipality land use classification into Residential, Tourism, Forestry, Agriculture, and Unused land which are given rating values of $0,2,5,5$ and 10 respectively (Figure 5. A).

Ministry of agriculture soil map was used to create soil map layer which is divided into three types of soils: Chestnut Soils Shallow phases, Chestnut Soils Deep phases and Rough Broken stony land. Rating values of 6,8 and 10 are given to each type of soil respectively (Figure 5.B). For the geological formation layer map, Aqr-Bekhma \&Komitan formation was given a rating value of 2, Slope and Alluvial fan deposits a rating value of 6, Balambo, Sarmord \&Qamchuqa formation a rating valyue of 4, Chia Gara, Barsarin \& Naokelekan formation a rating value of 8 and Sehkanian \& Sarki a rating value of 10 (Figure 5.C). The archeological site criterion was categorized into five buffer zones: (01000) m, (1000-2000) m, (2000-3000) m, (3000-4000) m and greater than $(4000) \mathrm{m}$. Rating values of $0,3,5,7$ and 10 were applied to the mentioned categories respectively (Figure 5.D).

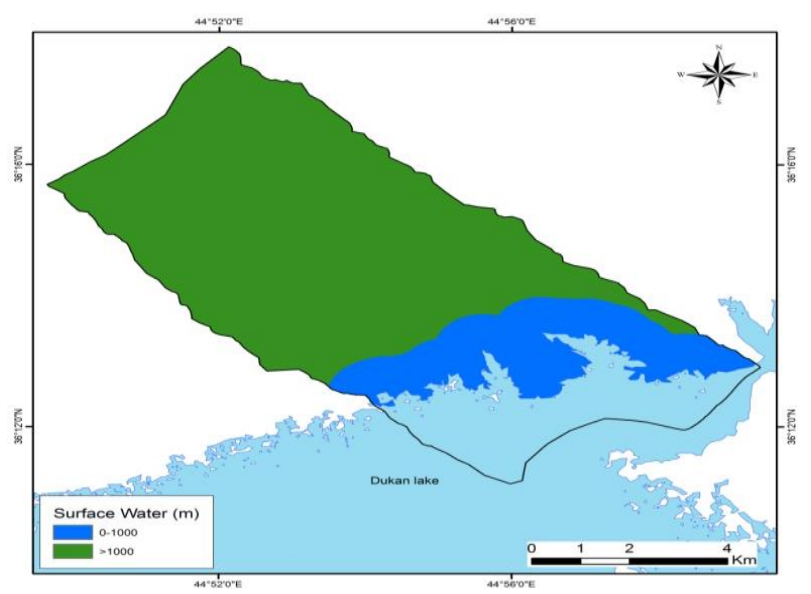

(a)

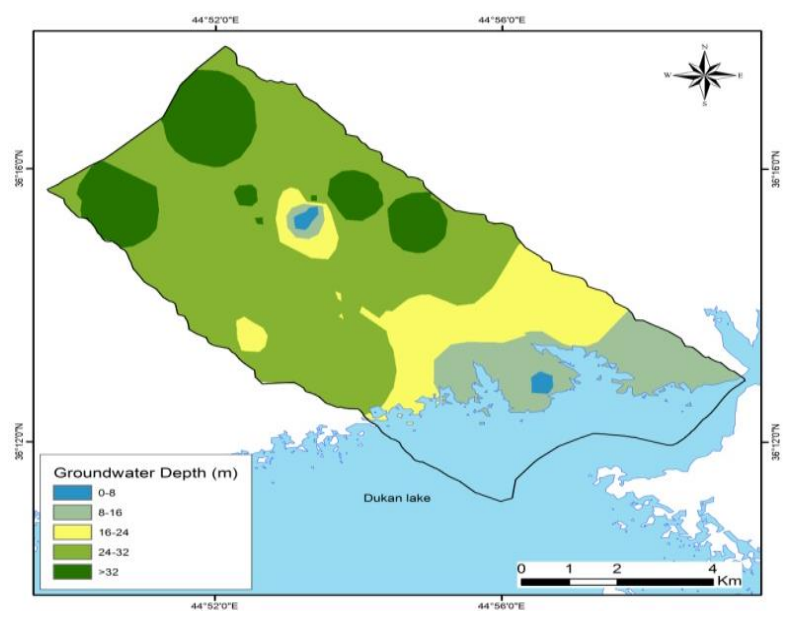

(b)

Figure 3. Buffer zones: (a) Surface Water, (b) Groundwater Depth. 


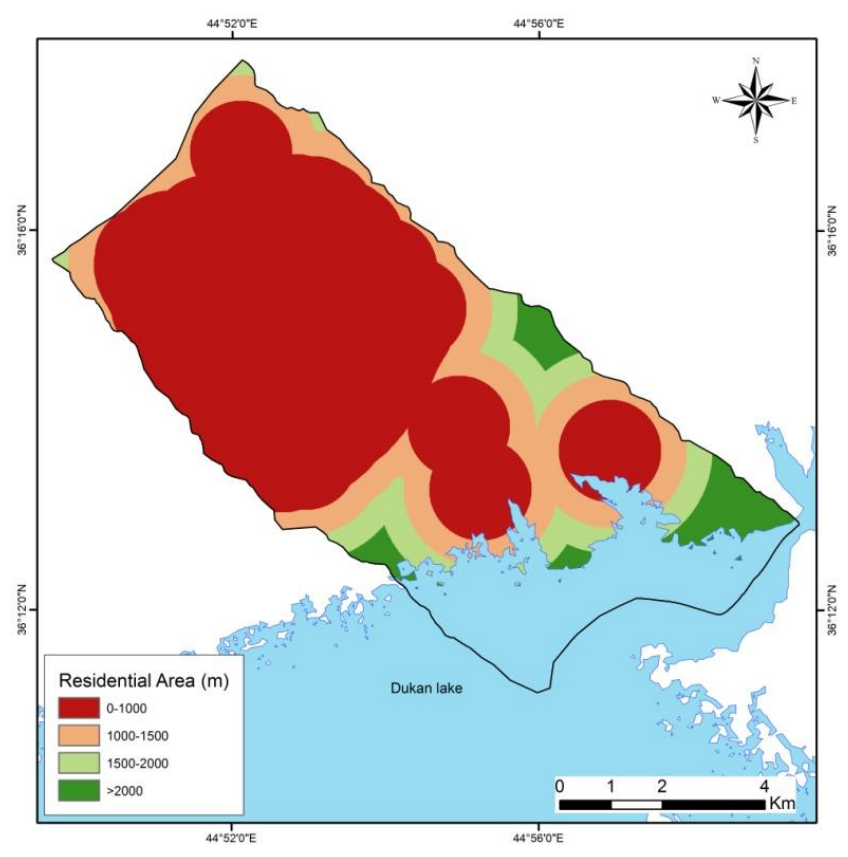

(a)

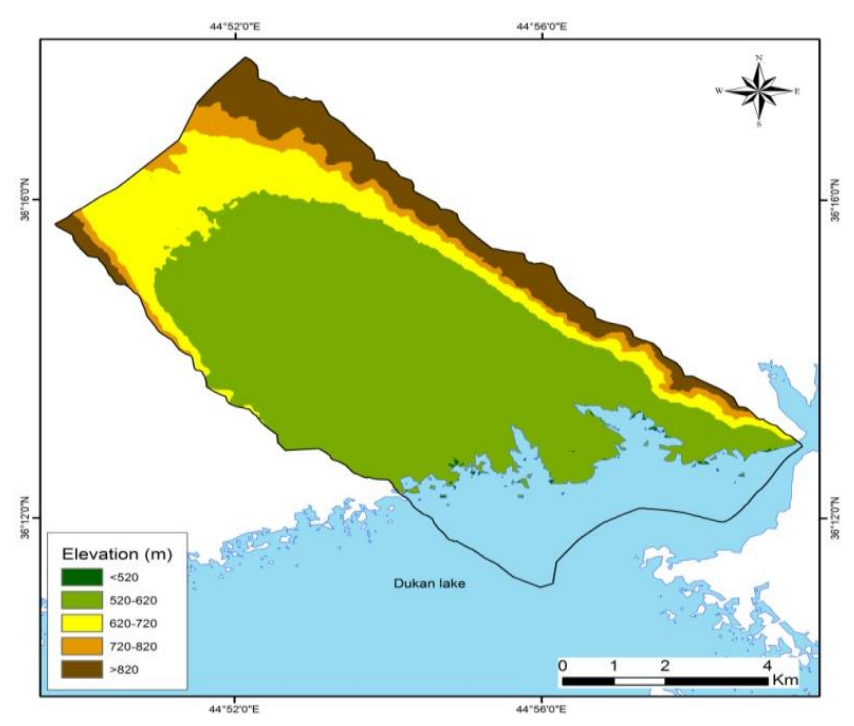

(b)

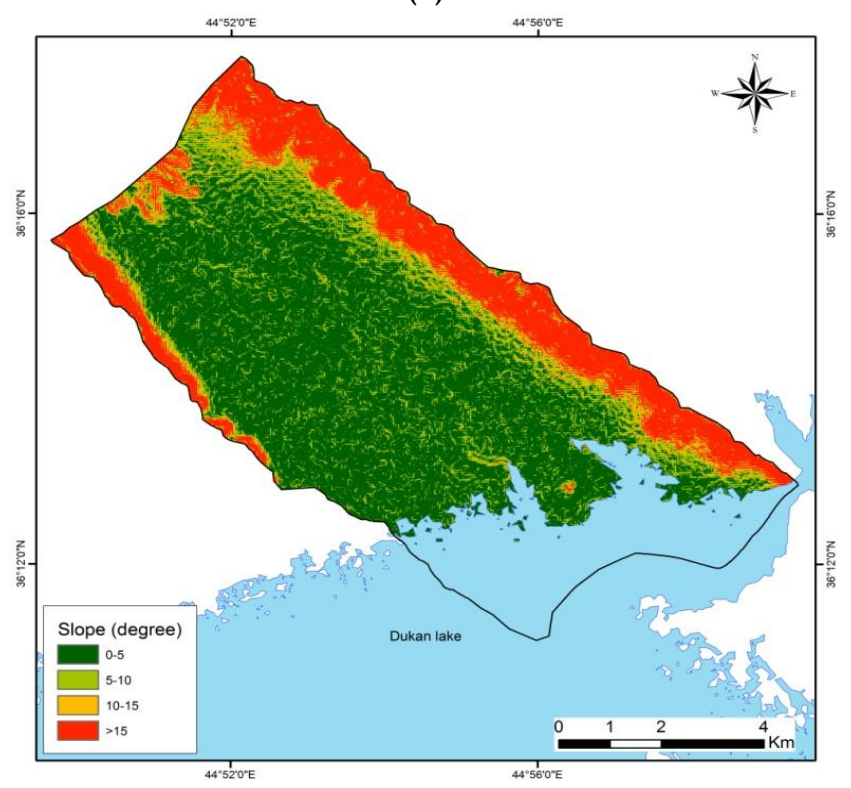

(c)

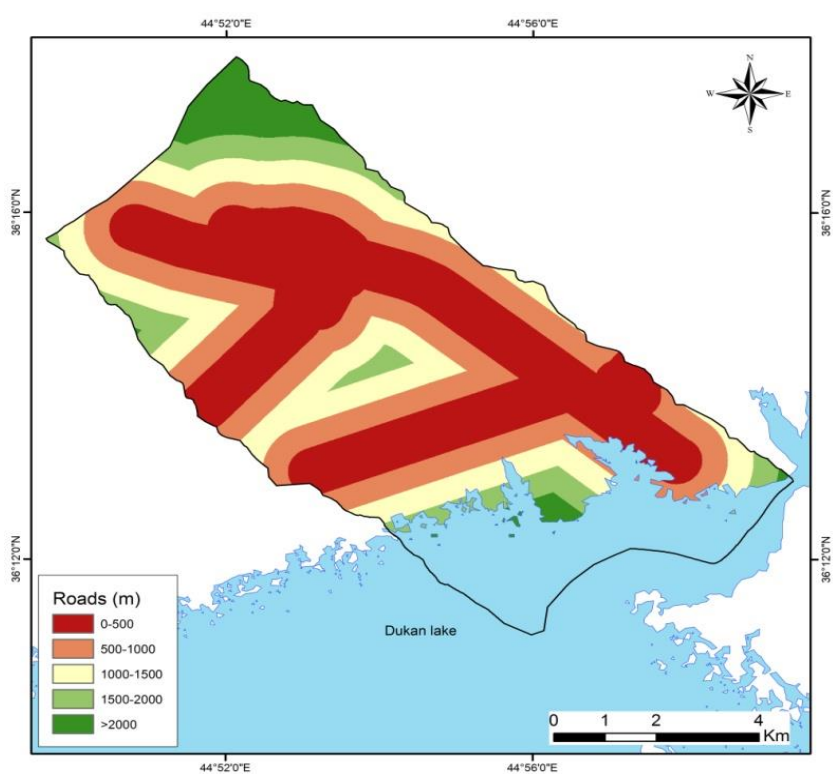

(d)

Figure 4. Buffer zones: (a) Residential area, (b) Elevation, (c) Slope, (d) Roads.

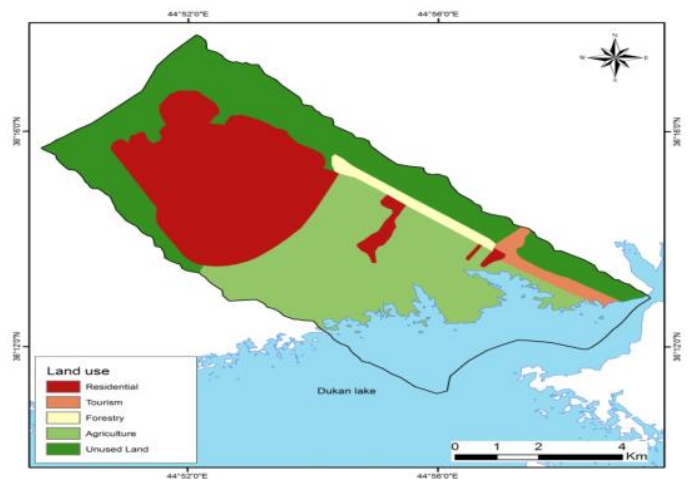

(a)

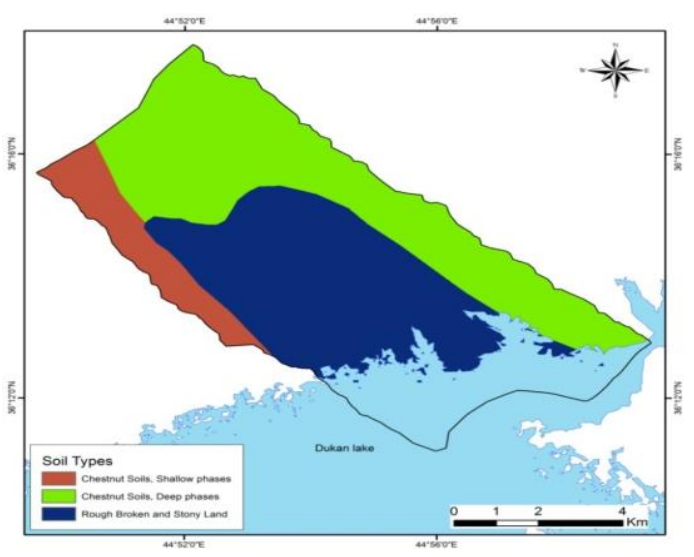

(b) 


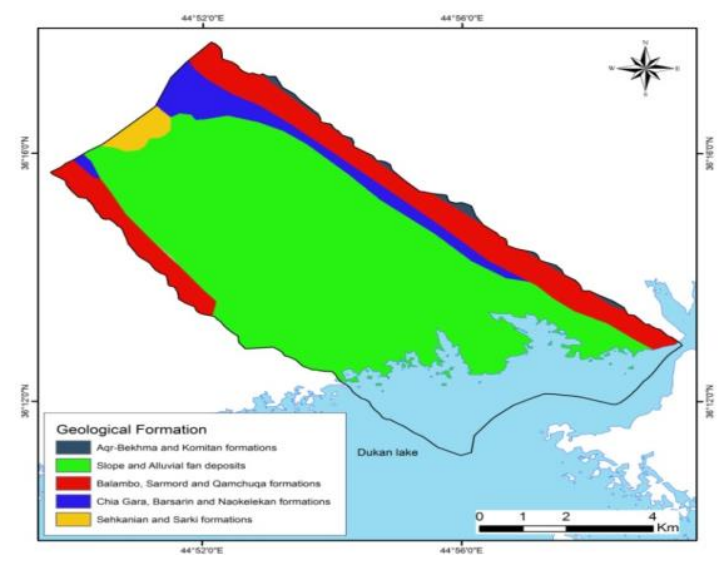

(c)

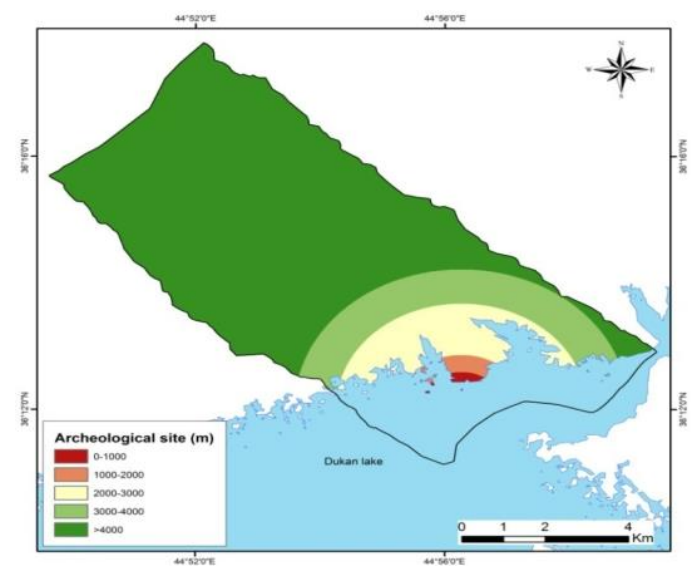

(d)

Figure 5. Buffer zones: (a) Land Use, (b) Soil Types, (c) Geological Formation, (d) Archeology site.

\subsection{AHP Method}

The analytical Hierarchy Process (AHP) was used to decide the relative weights for the criteria used in the present study using pairwise comparison matrix [42]. "AHP provides the judgment matrix by comparing the degree of significance of the relative element" [24]. The judgment process of pairwise comparison is done using a numerical scale of 9 points (Table 3.). The scale is used to signify the importance of one element in the matrix over another 9 being extreme importance while 1 being equal importance.

Pairwise comparison allows the decision maker to assess the contribution of each factor to the objective independently; this simplify the decision making process and allows the decision maker to choose the best strategy $[38,25]$.

Table 3. Relative importance Scale for the pairwise Comparisons [43]

\begin{tabular}{cc}
\hline \hline $\begin{array}{c}\text { Importance } \\
\text { Intensity }\end{array}$ & Definition \\
\hline 1 & "Equal importance" \\
2 & "Equal to moderate importance" \\
3 & "Moderate importance" \\
4 & "Moderate to strong importance" \\
5 & "Strong importance" \\
6 & "Strong to very strong \\
7 & importance" \\
8 & "Very strong importance" \\
9 & "Extreme importance" \\
\hline \hline
\end{tabular}

The decision matrix consists of numbers that are represented by $(m)$; while alternatives are given numbers represented by $(n)$. In order to implement a pair comparison in the matrix, every alternative can be evaluated in terms of the decision criteria, and each criterion can be estimated by its weight (relative scale of importance) [24]. A pairwise comparison is build in which the values of (aij) when $i=1,2, \ldots, \mathrm{m}$ and $j=1$, $2, \ldots, \mathrm{n}$ are used to indicate the performance values in terms of $i$ th and $j$ th in a matrix using equation (1) [38, $24,19]$.

$$
a i j=\frac{1}{a i}
$$

The typical comparison matrix is represented as below [3]:

$$
\left[\begin{array}{ccccc}
a_{11} & a_{12} & a_{13} & \cdots & a_{1 n} \\
a_{21} & a_{22} & a_{23} & \cdots & a_{2 n} \\
a_{31} & a_{32} & a_{33} & \cdots & a_{3 n} \\
\cdots & \cdots & \cdots & \cdots & \cdots \\
a_{m 1} & a_{m 2} & a_{m 3} & \cdots & a_{m n}
\end{array}\right]\left[\begin{array}{c}
W_{1} \\
W_{2} \\
W_{3} \\
\cdot \\
W_{n}
\end{array}\right]
$$

Geometric principles are used to calculate the eigenvectors for each row. The equation is presented as follows [24]:

$$
E g_{i}=(a 11 \times a 12 \times a 13 \ldots \times a 1 n) \frac{1}{n}
$$

Where, $E g_{i}=$ eigenvalue for the row $(i) ; n=$ number of variables in row $(i)$. 
Eigenevalue is normalized to 1 to compute AHP weight [44] as below:

$$
\operatorname{Pr}_{i}=\frac{E g_{i}}{\left(\sum_{i=1}^{n} E g_{i}\right)}
$$

Maximum Lambada $(\lambda \max )$ is derived from the summation of products between each element of the AHP weight and the sum of columns of the reciprocal matrix, as presented below equation [26]:

$$
\lambda \max =\sum_{j=1}^{n}\left\lceil W_{j} \sum_{i=1}^{m} a_{i j}\right\rceil
$$

Where, $a_{i j}$ is the criteria in each column, $W_{j}$ is the weight of each criterion that corresponds to priority vector in the matrix.

Consistency index $(C I)$ need to be computed to test consistency of decision matrix through the following equation [38]:

$$
C I=\frac{(\lambda \max -n)}{(n-1)}
$$

Where, $C I$ is consistency index, $\lambda \max$ is maximum lambada, $n$ is the number of the matrix. $C I$ in this study is 0.12

Inorder to ensure the consitency of pairwise comparison matrix, consistency judgement need to be tested [19]. Consistency ratio $(C R)$ must be less 0.1 at all times. The consistnecy ratio is calculated by dividing the consitency index value $(C I)$ by the random index value $(R I)$ [45]. In this study $R I=1.45$ because we have used 10 criteria Table 4.

$$
C R=\frac{C I}{R I}
$$

(CR) in this study is 0.08 which is less than 0.1 , thus it can be said that there is consistency and the AHP weight values are valid.

Table 4. Random inconsistency indices $[42,44]$

\begin{tabular}{ccccccccccccc}
\hline$n$ & 1 & 2 & 3 & 4 & 5 & 6 & 7 & 8 & 9 & 10 & 11 & 12 \\
\hline$R I$ & 0 & 0 & 0.58 & 0.90 & 1.12 & 1.24 & 1.32 & 1.41 & 1.45 & 1.49 & 1.51 & 1.48
\end{tabular}

As mentioned previously, the weights of each factor were determined based on expert opinion in the pairwise comparison matrix (Table 5)

Table 5. Pairwise comparison matrix to determine importance and weight of criteria

\begin{tabular}{c|cccccccccc|c}
\hline \hline & $\mathrm{A}$ & $\mathrm{B}$ & $\mathrm{C}$ & $\mathrm{D}$ & $\mathrm{E}$ & $\mathrm{F}$ & $\mathrm{G}$ & $\mathrm{H}$ & $\mathrm{I}$ & $\mathrm{J}$ & Weights\% \\
\hline $\mathrm{A}$ & 1.00 & 1.00 & 0.50 & 4.00 & 4.00 & 3.00 & 4.00 & 3.00 & 3.00 & 2.00 & 17 \\
$\mathrm{~B}$ & 1.00 & 1.00 & 0.33 & 2.00 & 2.00 & 2.00 & 3.00 & 3.00 & 4.00 & 2.00 & 13 \\
$\mathrm{C}$ & 2.00 & 3.00 & 1.00 & 4.00 & 3.00 & 4.00 & 4.00 & 4.00 & 7.00 & 6.00 & 25 \\
$\mathrm{D}$ & 0.25 & 0.50 & 0.25 & 1.00 & 0.50 & 0.50 & 2.00 & 3.00 & 5.00 & 5.00 & 9 \\
$\mathrm{E}$ & 0.25 & 0.50 & 0.33 & 2.00 & 1.00 & 0.50 & 2.00 & 2.00 & 3.00 & 3.00 & 8 \\
$\mathrm{~F}$ & 0.33 & 0.50 & 0.25 & 2.00 & 2.00 & 1.00 & 6.00 & 5.00 & 3.00 & 3.00 & 12 \\
$\mathrm{G}$ & 0.25 & 0.33 & 0.25 & 0.50 & 0.50 & 0.17 & 1.00 & 3.00 & 3.00 & 3.00 & 6 \\
$\mathrm{H}$ & 0.33 & 0.33 & 0.25 & 0.33 & 0.50 & 0.20 & 0.33 & 1.00 & 2.00 & 2.00 & 4 \\
$\mathrm{I}$ & 0.33 & 0.25 & 0.14 & 0.20 & 0.33 & 0.33 & 0.33 & 0.50 & 1.00 & 2.00 & 3 \\
$\mathrm{~J}$ & 0.50 & 0.50 & 0.17 & 0.20 & 0.33 & 0.33 & 0.33 & 0.50 & 0.50 & 1.00 & 3 \\
\hline \hline
\end{tabular}

(A) Groundwater Depth; (B) Surface Water; (C) Residential area; (D) Soil; (E) Elevation; (F) Slope; (G) Geological Formations; (H) Land Use; (I) Roads; (J) Archeological site.

\section{Results and Discussion}

After calculating the weights of the ten criteria from the pairwise comparison matrix, weighted overlay was performed for all map layers to obtain the landfill suitability map (Figure 6). Three classes of suitability index were obtained which are unsuitable, moderately suitable and suitable. The total matching area for unsuitable areas was about (75.62) $\mathrm{km}^{2}$ which represents $(98.47 \%)$ of the study area. Moderately suitable category represents a very small portion of the study area which is $(0.0023) \mathrm{km}^{2}$ or $(0.003 \%)$. The suitable area was $(1.17) \mathrm{km}^{2}$ which represents $(1.52 \%)$ of the study area.

The analysis shows most of the study area is unsuitable $(98.47 \%)$ for landfill site construction; this is largely due to limited land availability due to rapid urbanization in the study area. Also, the study area is surrounded by a series of mountains from east, north, and west and Dukan Lake from the southern border which makes it difficult for decision makers and 
authorities to decide on a landfill site. However, with the aid of GIS and AHP this study is proposing three suitable sites for landfill construction in Ranya city. The proposed sites have minimal impact on residential areas, agricultural land and are within a safe distance from Dukan Lake. The area of site (1) is $(0.29) \mathrm{km}^{2}$, site (2) is $(0.12) \mathrm{km}^{2}$ and site (3) is $(0.098) \mathrm{km}^{2}$. The sites proposed as suitable were validated with field visit. Generally, suitable sites comply with landfill site characteristics. However, a careful feasibility study should be conducted on the proposed sites to reduce environmental, economic and social impacts.

In Ranya city, the quantity of solid waste in 2038 is expected to be $(99,209.5)$ tones with a population of $(319,773)$ but the projected cumulative quantity of solid waste from 2018 to 2038 is expected to be $(364,167.8)$ tones. Based on the solid waste density average of $(450 \mathrm{~kg} / \mathrm{m} 3)$ by Ministry of Municipality, the expected volume of cumulative waste in 2038 is $(675,927) \mathrm{m} 3$. Hence, the required area to hold the expected volume of solid waste in the study area is $(0.16) \mathrm{km}^{2}$.

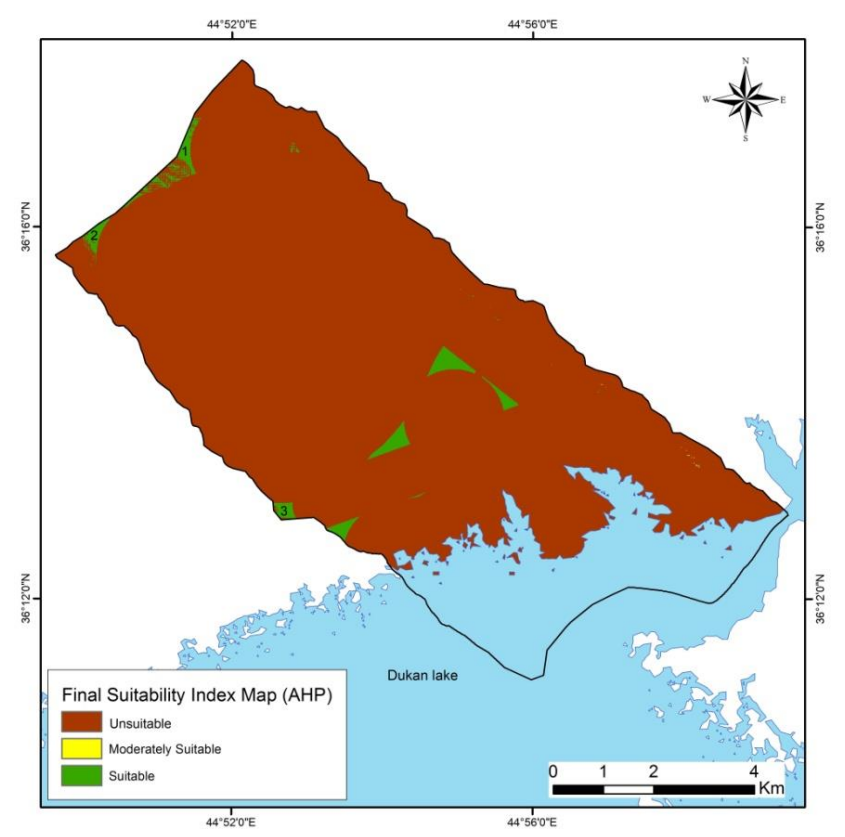

Figure 6. Landfill suitability map and candidate sites in the study area

\section{Conclusions}

Despite the growing concern of rapid solid waste generation rate, the current waste dumping sites in
Rany city do not comply with necessary environmental and scientific standards. The aim of this research was to select suitable landfill sites in Ranya City using GIS and AHP method by taking into consideration 10 criteria including groundwater, surface water, residential areas, soil, elevation, slope, geological formations, land use, roads and archeological sites.

Ten map layers were prepared using Arc GIS 10.8 and the criteria weightings were calculated from the AHP method using a pairwise comparison matrix. GIS has the ability to process large volume of data from various sources, and AHP allows for consistency check. The suitability map was produced using weighted overlay for the ten map layers. Three classes of suitability index were identified: unsuitable with a total matching area of $75.62 \mathrm{~km}^{2}(98.47 \%)$, moderately suitable represents $0.0023 \mathrm{~km} 2(0.003 \%)$ of the study area and suitable area with a total area of $1.17 \mathrm{~km}^{2}(1.52 \%)$ of the study area. The results signify that (98.47\%) of the study area is not suitable for landfill construction, this mostly due to land availability as a huge portion of the study area is already occupied by residential area including Ranya city and surrounding villages. In addition, natural geographic features such mountains and Dukan Lake.

\section{References}

1. TÜdeş, Ş., \& Kumlu, K. B. Y. (2017, October). Solid waste landfill site selection in the sense of environment sensitive sustainable urbanization: Izmir, Turkey case. In IOP Conference Series: Materials Science and Engineering (Vol. 245, No. 8, p. 82063).

2. Mian, M. M., Zeng, X., Nasry, A. A. N. B., \& AlHamadani, S. M. (2017). Municipal solid waste management in China: a comparative analysis. Journal of Material Cycles and Waste Management, 19(3), 1127-1135.

3. Chabuk, A., Al-Ansari, N., Hussain, H. M., Knutsson, S., \& Pusch, R. (2016). Landfill site selection using geographic information system and analytical hierarchy process: A case study Al-Hillah Qadhaa, Babylon, Iraq. Waste Management \& Research, 34(5), 427-437.

4. Al-Ansari, N., Al-Hanbali, A., \& Knutsson, S. (2012). Locating solid waste landfills in Mafraq City, Jordan. Journal of Advanced Science and Engineering Research, 2(1), 40-51.

5. Moeinaddini, M., Khorasani, N., Danehkar, A., \& Darvishsefat, A. A. (2010). Siting MSW landfill using 
weighted linear combination and analytical hierarchy process (AHP) methodology in GIS environment (case study: Karaj). Waste management, 30(5), 912-920.

6. Yesilnacar, M. I., \& Cetin, H. (2008). An environmental geomorphologic approach to site selection for hazardous wastes. Environmental Geology, 55(8), 16591671.

7. Siddiqui, M. Z., Everett, J. W., \& Vieux, B. E. (1996). Landfill siting using geographic information systems: a demonstration. Journal of environmental engineering, 122(6), 515-523.

8. Ersoy, H., \& Bulut, F. (2009). Spatial and multi-criteria decision analysis-based methodology for landfill site selection in growing urban regions. Waste Management E Research, 27(5), 489-500.

9. Abdullah, T. O., Ali, S. S., Al-Ansari, N. A., \& Knutsson, S. (2018). Possibility of Groundwater Pollution in Halabja Saidsadiq Hydrogeological Basin, Iraq Using Modified DRASTIC Model Based on AHP and Tritium Isotopes. Geosciences, 8(7), 236.

10. Li, Z. W., Zeng, G. M., Zhang, H., Yang, B., \& Jiao, S. (2007). The integrated eco-environment assessment of the red soil hilly region based on GIS - a case study in Changsha City, China. Ecological modelling, 202(3-4), 540-546.

11. Thapa, R. B., \& Murayama, Y. (2008). Land evaluation for peri-urban agriculture using analytical hierarchical process and geographic information system techniques: A case study of Hanoi. Land use policy, 25(2), 225-239.

12. Vahidnia, M. H., Alesheikh, A. A., \& Alimohammadi, A. (2009). Hospital site selection using fuzzy AHP and its derivatives. Journal of environmental management, 90(10), 3048-3056.

13. Sharifi, M., Hadidi, M., Vessali, E., Mosstafakhani, P., Taheri, K., Shahoie, S., \& Khodamoradpour, M. (2009). Integrating multi-criteria decision analysis for a GISbased hazardous waste landfill sitting in Kurdistan Province, western Iran. Waste management, 29(10), 27402758.

14. Effat, H. A., \& Hegazy, M. N. (2012). Mapping potential landfill sites for North Sinai cities using spatial multicriteria evaluation. The Egyptian Journal of Remote Sensing and Space Science, 15(2), 125-133.

15. Ramjeawon, T., \& Beerachee, B. (2008). Site selection of sanitary landfills on the small island of Mauritius using the analytical hierarchy process multi-criteria method. Waste management E research, 26(5), 439-447.

16. Yesilnacar, M. I., Süzen, M. L., Kaya, B. Ş., \& Doyuran, V. (2012). Municipal solid waste landfill site selection for the city of Şanliurfa-Turkey: an example using MCDA integrated with GIS. International Journal of Digital Earth, 5(2), 147-164.

17. Alavi, N., Goudarzi, G., Babaei, A. A., Jaafarzadeh, N., \& Hosseinzadeh, M. (2013). Municipal solid waste landfill site selection with geographic information systems and analytical hierarchy process: a case study in Mahshahr County, Iran. Waste Management $\mathcal{E}$ Research, 31(1), 98-105.
18. amdar, I., Ali, S., Bennui, A., Techato, K., \& Jutidamrongphan, W. (2019). Municipal solid waste landfill siting using an integrated GIS-AHP approach: A case study from Songkhla, Thailand. Resources, Conservation and Recycling, 149, 220-235.

19. Uyan, M. (2014). MSW landfill site selection by combining AHP with GIS for Konya, Turkey. Environmental earth sciences, 71(4), 1629-1639.

20. Vasiljević, T. Z., Srdjević, Z., Bajčetić, R., \& Miloradov, M. V. (2012). GIS and the analytic hierarchy process for regional landfill site selection in transitional countries: a case study from Serbia. Environmental management, 49(2), 445-458.

21. Isalou, A. A., Zamani, V., Shahmoradi, B., \& Alizadeh, H. (2013). Landfill site selection using integrated fuzzy logic and analytic network process (FANP). Environmental Earth Sciences, 68(6), 1745-1755.

22. Afzali, A., Sabri, S., Rashid, M., Samani, J. M. V., \& Ludin, A. N. M. (2014). Inter-municipal landfill site selection using analytic network process. Water resources management, 28(8), 2179-2194.

23. Delgado, O. B., Mendoza, M., Granados, E. L., \& Geneletti, D. (2008). Analysis of land suitability for the siting of inter-municipal landfills in the Cuitzeo Lake Basin, Mexico. Waste management, 28(7), 1137-1146.

24. Alkaradaghi, K., Ali, S. S., Al-Ansari, N., Laue, J., \& Chabuk, A. (2019). Landfill site selection using MCDM methods and GIS in the sulaimaniyah governorate, Iraq. Sustainability, 11(17), 4530.

25. Chabuk, A., Al-Ansari, N., Hussain, H. M., Knutsson, S., Pusch, R., \& Laue, J. (2017). Combining GIS applications and method of multi-criteria decision-making (AHP) for landfill siting in Al-Hashimiyah Qadhaa, Babylon, Iraq. Sustainability, 9(11), 1932.

26. Alkaradaghi, K., Ali, S. S., Al-Ansari, N., \& Laue, J. (2012). Landfill Site Selection Using GIS andMultiCriteria Decision-Making AHP and SAW Methods: A Case Study in SulaimaniyahGovernorate, Iraq: Landfill Site Selection Using GIS andMulti-Criteria DecisionMaking AHP and SAW Methods: A Case Study in SulaimaniyahGovernorate, Iraq. Engineerring, 4, 254268.

27. Rahmat, Z. G., Niri, M. V., Alavi, N., Goudarzi, G., Babaei, A. A., Baboli, Z., \& Hosseinzadeh, M. (2017). Landfill site selection using GIS and AHP: a case study: Behbahan, Iran. KSCE Journal of Civil Engineering, 21(1), 111-118.

28. Maiti, S. K., De, S., Hazra, T., Debsarkar, A., \& Dutta, A. (2016). Characterization of leachate and its impact on surface and groundwater quality of a closed dumpsitea case study at Dhapa, Kolkata, India. Procedia Environmental Sciences, 35, 391-399.

29. Kharat, M. G., Kamble, S. J., Raut, R. D., \& Kamble, S. S. (2016). Identification and evaluation of landfill site selection criteria using a hybrid Fuzzy Delphi, Fuzzy AHP and DEMATEL based approach. Modeling Earth Systems and Environment, 2(2), 98.

30. Demesouka, O. E., Vavatsikos, A. P., \& 
Anagnostopoulos, K. P. (2014). GIS-based multicriteria municipal solid waste landfill suitability analysis: A review of the methodologies performed and criteria implemented. Waste Management \& Research, 32(4), 270296.

31. Pasalari, H., Nodehi, R. N., Mahvi, A. H., Yaghmaeian, K., \& Charrahi, Z. (2019). Landfill site selection using a hybrid system of AHP-Fuzzy in GIS environment: A case study in Shiraz city, Iran. Methods X, 6, 1454-1466.

32. Chang, N. B., Parvathinathan, G., \& Breeden, J. B. (2008). Combining GIS with fuzzy multicriteria decisionmaking for landfill siting in a fast-growing urban region. Journal of environmental management, 87(1), 139153.

33. Eskandari, M., Homaee, M., \& Mahmodi, S. (2012). An integrated multi criteria approach for landfill siting in a conflicting environmental, economical and sociocultural area. Waste Management, 32(8), 1528-1538.

34. Yildirim, V. (2012). Application of raster-based GIS techniques in the siting of landfills in Trabzon Province, Turkey: a case study. Waste Management $\mathcal{E}$ Research, 30(9), 949-960.

35. Nas, B., Cay, T., Iscan, F., \& Berktay, A. (2010). Selection of MSW landfill site for Konya, Turkey using GIS and multi-criteria evaluation. Environmental monitoring and assessment, 160(1-4), 491.

36. Şener, B., Süzen, M. L., \& Doyuran, V. (2006). Landfill site selection by using geographic information systems. Environmental geology, 49(3), 376-388.

37. Charnpratheep, K., Zhou, Q., \& Garner, B. (1997). Preliminary landfill site screening using fuzzy geographical information systems. Waste management $\mathcal{E}$ research, 15(2), 197-215.

38. Şener, Ş., Sener, E., \& Karagüzel, R. (2011). Solid waste disposal site selection with GIS and AHP methodology: a case study in Senirkent-Uluborlu (Isparta) Basin, Turkey. Environmental monitoring and assessment, 173(14), 533-554.

39. Baiocchi, V., Lelo, K., Polettini, A., \& Pomi, R. (2014). Land suitability for waste disposal in metropolitan areas. Waste management $\mathcal{E}$ research, 32(8), 707-716.

40. Buringh, P. (1960). Soils and soil conditions in Iraq. Ministry of agriculture.

41. Kurdistan Regional Government, Ministry of Municipality and Tourism.," Ranya Muncipality, internal records, 2018.

42. Feizizadeh, B., Jankowski, P., \& Blaschke, T. (2014). A GIS based spatially-explicit sensitivity and uncertainty analysis approach for multi-criteria decision analysis. Computers $\mathcal{E}$ geosciences, 64, 81-95.

43. Mohd, Z. H., \& Ujang, U. (2016). Integrating multiple criteria evaluation and GIS in ecotourism: a review. The International Archives of Photogrammetry, Remote Sensing and Spatial Information Sciences, 42, 351.

44. á Saaty, T. L. (1980). The Analytic Hierarchy Process: Planning, Priority Setting. Resource Allocation.

45. Ghorbanzadeh, O., Pourmoradian, S., Blaschke, T., \& Feizizadeh, B. (2019). Mapping potential nature-based tourism areas by applying GIS-decision making systems in East Azerbaijan Province, Iran. Journal of Ecotourism, 18(3), 261-283. 